\title{
La red Openergy
}

\section{The Openergy Network}

\section{Editorial de la revista}

Francisco José García-Peñalvo

Departamento de Informática y Automática / Instituto de Ciencias de la Educación / Grupo GRIAL

Director Científico / Editor-In-Chief Education in the Knowledge Society Journal

Universidad de Salamanca, España

fgarcia@usal.es (http://orcid.org/0000-0001-9987-5584)

\section{Resumen}

En octubre de 2018 tuvo lugar la tercera reunión de la Red Internacional Openergy en el Tecnológico de Monterrey (México). Este número de EKS se dedica de forma monográfica a que diferentes miembros de esta Red presenten el trabajo que se está desarrollando.

\section{Palabras Clave}

Openergy; Redes de investigación; Ciencia abierta

\begin{abstract}
In October 2018, the third meeting of the Openergy International Network took place at the Tecnológico de Monterrey (Mexico). This issue of EKS is dedicated in a monographic way to different members of this Network present the work that is being developed.
\end{abstract}

\section{Keywords}

Openergy; Research networks; Open Science

\section{Openergy}

Dentro del marco del proyecto "Laboratorio Binacional para la Gestión Inteligente de la Sustentabilidad Energética y la Formación Tecnológica”, desarrollado entre México y EEUU y liderado por el Tecnológico de Monterrey, se ha constituido de forma multidisciplinar y trasnacional la Red de Investigación Openergy.

Esta Red tiene como objetivo promover nodos de conexión para la colaboración entre diversas instituciones, organismos sociales y gubernamentales, con el propósito de promover la educación (Fidalgo-Blanco, Sein-Echaluce Lacleta, Borrás Gené \& García-Peñalvo, 2014; García-Peñalvo, FidalgoBlanco \& Sein-Echaluce, 2018; McGreal, Kinuthia \& Marshall, 2013; Ramírez-Montoya \& García-Peñalvo, 2015; Ramírez-Montoya, García-Peñalvo \& McGreal, 2018) e innovación abierta (European Commission, 2016; García-Peñalvo, García de Figuerola \& Merlo-Vega, 2010; Ramírez-Montoya \& García-Peñalvo, 2018; Yañez-Figueroa, Ramírez-Montoya \& García-Peñalvo, 2016) para la sustentabilidad energética.

Se buscar crear diversas estrategias y sinergias que influyan en la construcción de escenarios y nuevas posibilidades para fortalecer el núcleo social de una comunidad. Además, se desea compartir la investigación generada y aplicarla para resolver problemas de la sociedad y para generar una base de conocimientos a partir de prácticas de gestión de información y del conocimiento a través del uso 
de las tecnologías de la información y de la comunicación, en un ejemplo de colaboración entre la academia y el tejido productivo (Etzkowitz \& Leydesdorff, 1997; García-Peñalvo, 2016).

En octubre de 2018, en el Tecnológico de Monterrey (Monterrey, México) se organizó la tercera reunión de esta Red. En esta ocasión participaron 38 investigadores, divididos en cinco equipos, con el objetivo de diseñar futuros proyectos que den continuidad y nuevos planteamientos al trabajo realizado en el marco del Proyecto "Laboratorio Binacional para la Gestión Inteligente de la Sustentabilidad Energética y la Formación Tecnológica".

Entre los participantes en esta reunión se hizo un llamamiento para conformar un monográfico en EKS en el que quedaran claros los principios y actividades tanto del Proyecto Laboratorio Binacional como de la Red Openergy. Finalmente, se han seleccionado siete artículos que constituyen los contenidos de este último número de 2018 en la revista EKS.

\section{Agradecimientos}

Este artículo se registra en el marco del Proyecto 266632 "Laboratorio Binacional para la Gestión Inteligente de la Sustentabilidad Energética y la Formación Tecnológica", con financiamiento del

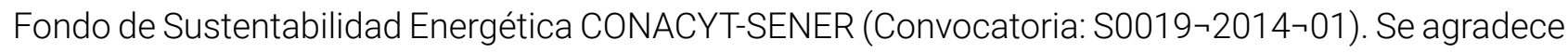
el apoyo al CONACYT y al Tecnológico de Monterrey como responsable del proyecto.

Explícitamente se quiere expresar el agradecimiento de todos los miembros de la Red Openergy a su coordinadora, la Dra. María Soledad Ramírez Montoya, tanto por su liderazgo a la hora de coordinar el esfuerzo humano y material que requiere una red de investigación como por su buen hacer para conseguir resultados tangibles que permiten seguir creando puentes entre instituciones e investigadores de los cinco continentes.

\section{Openergy}

Within the framework of the project "Laboratorio Binacional para la Gestión Inteligente de la Sustentabilidad Energética y la Formación Tecnológica", developed between Mexico and the USA and led by the Tecnológico de Monterrey, the Openergy Research Network has been constituted in a multidisciplinary and transnational way.

This Network aims to promote connection nodes for collaboration between various institutions, social and governmental organizations, with the purpose of promoting education (Fidalgo-Blanco et al., 2014; García-Peñalvo et al., 2018; McGreal et al., 2013; Ramírez-Montoya \& García-Peñalvo, 2015; Ramírez- 
Montoya et al., 2018) and open innovation (European Commission, 2016; García-Peñalvo et al., 2010; Ramírez-Montoya \& García-Peñalvo, 2018; Yañez-Figueroa et al., 2016) for energy sustainability.

We seek to create diverse strategies and synergies that influence the construction of scenarios and new possibilities to strengthen the social nucleus of a community. In addition, it is desired to share the generated research and apply it to solve society's problems and to generate a knowledge base from information and knowledge management practices through the use of information and communication technologies, in an example of collaboration between the academy and the social and economic agents (Etzkowitz \& Leydesdorff, 1997; García-Peñalvo, 2016).

In October 2018, at the Tecnológico de Monterrey (Monterrey, Mexico), the third meeting of this Network was organised. On this occasion 38 researchers participated, divided into five teams, with the aim of designing future projects that provide continuity and new approaches to the work carried out within the framework of the Project "Laboratorio Binacional para la Gestión Inteligente de la Sustentabilidad Energética y la Formación Tecnológica”.

Among the participants in this meeting, a call was made to set up a monograph on EKS in which the principles and activities of both the Binational Laboratory Project and the Openergy Network will be presented. Finally, seven articles have been selected that constitute the contents of this latest issue of 2018 in the EKS journal.

\section{Acknowledgments}

This article is related to Project 266632 "Laboratorio Binacional para la Gestión Inteligente de la Sustentabilidad Energética y la Formación Tecnológica", supported by the Energy Sustainability Fund CONACYT-SENER (Call: S0019-2014-01). We appreciate the support to CONACYT and the Tecnológico de Monterrey as responsible for the project.

Explicitly, we want to express the gratitude of all members of the Openergy Network to its coordinator, Dr. María Soledad Ramírez Montoya, both for her leadership in coordinating the human and material effort required by a research network and for her good to achieve tangible results that allow us to continue creating bridges between institutions and researchers from the five continents.

\section{Referencias / References}

Etzkowitz, H. \& Leydesdorff, L. (1997). Universities and the Global Knowledge Economy. A triple of a Triple Helix of University-Industry-Government Relations. London: Pinter. 
European Commission. (2016). Open innovation, open science, open to the world. A vision for Europe. Brussels: Directorate-General for Research and Innovation, European Commission.

Fidalgo-Blanco, Á., Sein-Echaluce Lacleta, M. L., Borrás Gené, O. \& García-Peñalvo, F. J. (2014). Educación en abierto: Integración de un MOOC con una asignatura académica. Education in the Knowledge Society, 15(3), 233-255.

García-Peñalvo, F. J. (2016). The Third Mission. Education in the Knowledge Society, 17(1), 7-18. doi: $10.14201 /$ eks2016171718

García-Peñalvo, F. J., Fidalgo-Blanco, Á. \& Sein-Echaluce, M. L. (2018). An adaptive hybrid MOOC model: Disrupting the MOOC concept in higher education. Telematics and Informatics, 35, 1018-1030. doi:10.1016/j.tele.2017.09.012

García-Peñalvo,F.J.,GarcíadeFiguerola,C.\&Merlo-Vega,J.A.(2010). Openknowledge:Challenges and facts. Online Information Review, 34(4), 520-539. doi: 10.1108/14684521011072963

McGreal, R., Kinuthia, W. \& Marshall, S. (Eds.). (2013). Open Educational Resources: Innovation, Research and Practice. Vancouver, Canada: Commonwealth of Learning and Athabasca University.

Ramírez-Montoya, M. S. \& García-Peñalvo, F. J. (2015). Movimiento Educativo Abierto. Virtualis, 6(12), 1-13.

Ramírez-Montoya, M. S. \& García-Peñalvo, F. J. (2018). Co-creation and open innovation: Systematic literature review. Comunicar, 26(54), 9-18. doi: 10.3916/C54-2018-01

Ramírez-Montoya, M. S., García-Peñalvo, F. J. \& McGreal, R. (2018). Shared Science and Knowledge. Open Access, Technology and Education. Comunicar, 26(54), 1-5.

Yañez-Figueroa, J. A., Ramírez-Montoya, M. S. \& García-Peñalvo, F. J. (2016). Open innovation laboratories for social modeling sustainable society sensitive to social needs. In F. J. GarcíaPeñalvo (Ed.), Proceedings of the Fourth International Conference on Technological Ecosystems for Enhancing Multiculturality (TEEM'16) (Salamanca, Spain, November 2-4, 2016) (pp. 11331138). New York, NY, USA: ACM. 